\title{
Analisis Spasial Persebaran dan Pemetaan Kerawanan Kejadian Kasus Demam Berdarah Dengue di Kabupaten Lumajang dengan Spatial Pattern Analysis dan Flexibly Shaped Spatial Scan Statistic
}

\author{
Abimanyu Kurniadi dan Sutikno \\ Departemen Statistika, Fakultas Matematika, Komputasi, dan Sains Data, \\ Institut Teknologi Sepuluh Nopember (ITS) \\ e-mail: sutikno@statistika.its.ac.id
}

\begin{abstract}
Abstrak-Kabupaten Lumajang cenderung mengalami peningkatan jumlah kasus kejadian demam berdarah dengue atau DBD. Hal ini menunjukkan bahwa, jumlah kejadian kasus DBD di Kabupaten Lumajang belum dapat ditekan secara efektif, kemungkinan disebabkan oleh kurangnya informasi terhadap waktu, tempat dan jumlah kejadian kasus DBD yang terintegrasi. Salah satu faktor yang menyebabkan terjadinya peningkatan kasus DBD dapat ditinjau dari aspek spasial, yaitu tingkat ketergantungan penyakit DBD di suatu wilayah diperkirakan dipengaruhi oleh penyakit DBD di wilayah lain yang berdekatan. Kejadian kasus DBD yang digunakan dalam penelitian ini adalah kejadian kasus DBD di setiap kecamatan di Kabupaten Lumajang pada Tahun 2014-2016 yang kemudian dianalisis dengan menggunakan Spatial Pattern Analysis dan Flexibly Shaped Spatial Scan Statistic untuk menganalisis pola persebaran dan membentuk peta kerawanan. Hasil penelitian menyimpulkan pola persebaran kejadian kasus DBD pada Tahun 2014 yaitu menyebar, sedangkan Tahun 2015 dan 2016 pola persebarannya mengelompok. Hasil analisis dengan menggunakan metode Flexibly Shaped Spatial Scan Statistic mengidentifikasi kecamatan rawan kasus DBD yaitu Kecamatan Gucialit, Klakah, Padang, Sukodono, Lumajang, Sumbersuko, Tempeh, Rowokangkung Yosowilangun dan Tekung. Kecamatan Lumajang adalah kecamatan yang selalu memiliki jumlah kasus DBD yang tertinggi atau maksimum pada Tahun 2014 hingga 2016.
\end{abstract}

Kata Kunci-DBD, Flexibly Shaped Spatial Scan Statistic, Lumajang, Spatial Pattern Analysis.

\section{PENDAHULUAN}

$\mathrm{D}$ EMAM berdarah dengue (DBD) adalah suatu penyakit yang disebabkan oleh infeksi virus dengue. Virus ini bisa masuk ke dalam tubuh manusia dengan perantara nyamuk Aedes aegypti dan Aedes albopictus. Kedua jenis nyamuk ini terdapat hampir di seluruh pelosok Indonesia, kecuali di tempat-tempat ketinggian lebih dari 1000 meter di atas permukaan laut. Oleh karena itu, seluruh wilayah di Indonesia mempunyai resiko untuk terjangkit penyakit DBD [1].

DBD di Jawa Timur cenderung meningkat, berdasarkan data dari Profil Kesehatan Kabupaten Lumajang, di wilayah Kabupaten Lumajang jumlah kejadian kasus DBD mengalami tren kenaikan, tahun 2014 terjadi 129 kasus menjadi 179 kasuspada tahun 2015. Tahun 2016 juga terjadi peningkatan jumalah kasus DBD dari tahun 2015, yaitu dari 179 kasus menjadi 312 kasus. Hal ini menunjukkan bahwa, jumlah kejadian kasus DBD di Kabupaten Lumajang belum dapat ditekan secara efektif, kemungkinan disebabkan oleh kurangnya informasi terhadap waktu, tempat dan jumlah kejadian kasus DBD yang terintegrasi. Selama ini di Kabupaten Lumajang belum pernah ada penelitian tentang persebaran dan pemetaan kerawanan kejadian kasus DBD yang dipublikasikan. Informasi sebaran wilayah rawan menurut tempat dan waktu diperlukan dalam menetukan wilayah prioritas pelaksanaan program antisipasi dan penanggulangan terhadap suatu penyakit [2].

Banyak faktor yang menyebabkan terjadinya peningkatan kasus DBD, antara lain nyamuk sebagai vektor, faktor lingkungan, dan unsur iklim yang dapat ditinjau dari aspek spasial. Aspek spasial (wilayah) penting untuk dikaji, karena antara satu wilayah dengan wilayah lain mempunyai perbedaan karakteristik, seperti ketinggian permukaan tanah, jenis tanah, kepadatan dan perilaku penduduk, tingkat kebersihan lingkungan, dan lain sebagainya [3]. Peta sebaran geografis sangat berguna untuk mempelajari hubungan antara geografis dengan penyakit secara empirik dan bermanfaat untuk membantu mengimplementasikan rencana intervensi.

Penelitian ini akan menganalisis pola persebaran kejadian kasus DBD dengan peta tematik dan secara inferensia menggunakan metode Spatial Pattern Analysis dengan mempertimbangkan aspek wilayah (kecamatan) dan waktu (tahun), serta membentuk peta kerawanan melalui metode Flexibly Shaped Spatial Scan Statistic. Penelitian sebelumnya yang menggunakan metode ini pernah dilakukan oleh Hibatullah [4] yaitu tentang kejadian kasus pneumonia balita di Kota Surabaya. 


\section{TINJAUAN PUSTAKA}

\section{A. Statistik Deskriptif}

Statistika deskriptif merupakan bagian dari statistika yang membahas tentang metode-metode untuk menyajikan data sehigga menarik dan informatif. Secara umum, statistika deskriptif dapat diartikan sebagai metode-metode yang berkaitan dengan pengumpulan dan penyajian suatu gugus data sehingga memberikan informasi yang berguna. Statistika deskriptif memberikan informasi hanya mengenai data yang dipunyai dan sama sekali tidak menarik inferensia [5].

\section{B. Boxplot}

Boxplot adalah salah satu cara dalam statistika deskriptif unutk menggambarkan secara grafik dari data numeris melalui lima ukuran sebagai berikut.

1. Nilai terendah dalam batas bawah

2. Kuartil pertama (Q1), yang memotong $25 \%$ dari data terendah

3. Median (Q2) atau nilai pertengahan, yang memotong $50 \%$ dari data

4. Kuartil ketiga (Q3), yang memotong $25 \%$ dari data tertinggi

5. Nilai tertinggi dalam batas atas

Dalam boxplot juga ditunjukkan, jika ada, nilai outlier dari observasi. Jarak antara bagian-bagian dari box menunjukkan derajat dispersi (penyebaran) dan skewness (kecondongan) dalam data. Dalam penggambarannya, boxplot dapat digambarkan secara horizontal maupun vertikal [6].

Ilustrasi dari boxplot lebih lanjut dapat dilihat seperti pada Gambar 1.

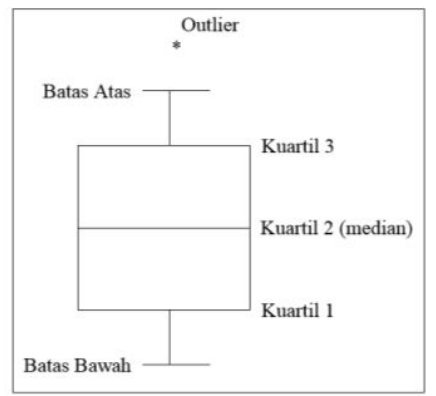

Gambar 1. Ilustrasi Boxplot.

\section{Spatial Pattern}

Spatial pattern atau pola spasial adalah sesuatu yang menunjukkan penempatan atau susunan benda-benda di permukaan bumi [7]. Setiap perubahan spatial pattern akan mengilustrasikan proses spasial yang ditunjukkan oleh faktorfaktor lingkungan dan budaya. Spatial pattern suatu obyek geografis merupakan hasil dari proses fisik atau sosial di suatu lokasi di permukaan bumi. Kemudian Spatial pattern menjadi suatu konsep statistik, ketika pola tersebut menunjukkan bagaimana objek geografis terdistribusi pada suatu waktu tertentu.

\section{Autokorelasi Spasial}

Autokorelasi spasial adalah korelasi antara variabel dengan dirinya sendiri berdasarkan ruang atau dapat juga diartikan suatu ukuran kemiripan dari objek di dalam suatu ruang (jarak, waktu dan wilayah) [7]. Adanya autokorelasi spasial mengindikasikan bahwa nilai attribut pada daerah tertentu terkait oleh nilai attribut tersebut pada daerah lain yang letaknya berdekatan.

\section{E. Matriks Pembobot Spasial}

Matriks pembobot spasial $W$ berdasarkan persentuhan batas wilayah (contiguity) menyatakan bahwa interaksi spasial terjadi antar wilayah yang bertetangga [8]. Secara umum, terdapat 3 tipe interaksi, yaitu Rook Contiguity (persentuhan sisi), Bishop Contiguity (persentuhan titik vertek), dan Queen Contiguity (persentuhan sisi dan titik vertek). Wilayah yang bertetanggaan diberikan nilai 1 , sedangkan yang lain 0 .

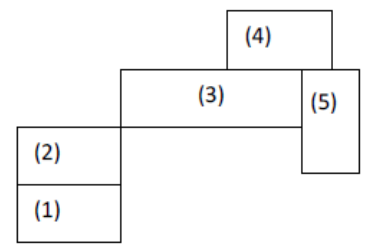

Gambar 2. Ilustrasi Contiguity.

Dengan menggunakan Queen Contiguity untuk Gambar 2. didapatkan matriks $W$ sebagai berikut.

$$
\mathbf{W}_{\text {queen }}=\left[\begin{array}{lllll}
0 & 1 & 0 & 0 & 0 \\
1 & 0 & 1 & 0 & 0 \\
0 & 1 & 0 & 1 & 1 \\
0 & 0 & 1 & 0 & 1 \\
0 & 0 & 1 & 1 & 0
\end{array}\right]
$$

\section{F. Moran's I}

Moran's I mengukur korelasi satu variabel misal $x$ ( $x_{i}$ dan $x_{j}$ ) dimana $i \neq j, i=1,2, \ldots, n, j=1,2, \ldots . n$ dengan banyak data sebesar $n$, maka formula dari Moran's I adalah pada persamaan (2.2).

$$
\hat{I}=\frac{n \sum_{i=1}^{n} \sum_{j=1}^{n} w_{i j}\left(x_{i}-\bar{x}\right)\left(x_{j}-\bar{x}\right)}{S_{0} \sum_{i=1}^{n}\left(x_{i}-\bar{x}\right)^{2}}
$$

Dengan $\bar{x}$ merupakan rata-rata dari variabel $x, w_{i j}$ merupakan elemen dari matrik pembobot, dan $S_{0}=\sum_{i} \sum_{j} w_{i j}$. Nilai dari indeks $\hat{\boldsymbol{I}}$ ini berkisar antara -1 sampai 1. Jika $\hat{\boldsymbol{I}}>$ $I_{0}$, maka mempunyai pola mengelompok (autokorelasi positif), jika $\hat{\boldsymbol{I}}=I_{0}$, maka berpola menyebar tidak merata (tidak ada autokorelasi), dan $\hat{\boldsymbol{I}}<I_{0}$, memiliki pola menyebar (autokorelasi negatif). $I_{0}$ merupakan nilai ekspektasi dari $\boldsymbol{I}$ yang dirumuskan $E(I)=\frac{-1}{n-1}$ [7]. Pengujian hipotesis terhadap parameter $I$ dapat dilakukan sebagai berikut.

$\mathrm{H}_{0}: \quad \boldsymbol{I}=I_{0}$ (tidak ada autokorelasi spasial)

$\mathrm{H}_{1}: \quad I \neq I_{0}$ (terdapat autokorelasi spasial)

$$
Z=\frac{\hat{I}-I_{0}}{\sqrt{(\operatorname{var}(\hat{I}))}}
$$

Dengan $\hat{\boldsymbol{I}}$ adalah estimasi indeks Moran's I, $Z$ adalah nilai statistik uji indeks Moran's I, $E(I)$ adalah nilai 
ekspektasi indeks Moran's I, dan $\operatorname{var}(I)$ adalah nilai varians indeks Moran's I.

$$
\begin{aligned}
& \operatorname{var}(I)=\frac{n\left\{\left(n^{2}-3 n+3\right) S_{1}-n S_{2}+3 S_{0}^{2}\right\}}{(n-1)(n-2)(n-3) S_{0}^{2}}-\frac{k\left\{n(n-1) S_{1}-n S_{2}+3 S_{0}^{2}\right\}}{(n-1)(n-2)(n-3) S_{0}^{2}} \\
& -\frac{1}{(n-1)^{2}}
\end{aligned}
$$

\section{Dengan,}

$k=\sum_{i=1}^{n}\left(x_{i}-\bar{x}\right)^{4} /\left(\left(\sum_{i=1}^{n}\left(x_{i}-\bar{x}\right)^{2}\right)^{2}\right.$

$S_{1}=\frac{1}{2} \sum_{i=1}^{n} \sum_{j=1}^{n}\left(w_{i j}+w_{j i}\right)^{2}$

$S_{2}=\sum_{i=1}^{n}\left(w_{i .}+w_{. i}\right)^{2}, w_{i .}=\sum_{j=1}^{n} w_{i j}$ dan $w_{. i}=\sum_{j=1}^{n} w_{j i}$

Pengujian ini akan menolak hipotesis awal apabila nilai $\left|\mathrm{Z}_{\text {hitung }}\right|>\mathrm{Z}_{(\alpha / 2)}$ atau P-value $<\alpha$. Nilai dari indeks I adalah anatara -1 sampai 1. Apabila $\mathrm{I}>\mathrm{I}_{0}$ maka data memiliki autokorelasi positif, jika $\mathrm{I}>\mathrm{I}_{0}$ maka data memiliki autokorelasi negatif

\section{G. Moran's Scatterplot}

Moran's Scatterplot merupakan alat untuk melihat hubungan antara nilai pengamatan yang telah distandarisasi dengan nilai rata-rata daerah tetangga yang juga telah distandarisasi [7]. Untuk lebih jelasnya, dapat dilihat pada ilustrasi berikut.

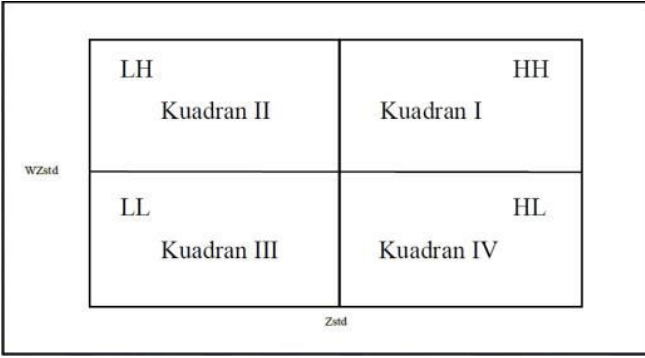

Gambar 3. Moran's Scatterplot

Kuadran I (kanan atas) disebut High-High (HH), menunjukkan daerah yang mempunyai nilai pengamatan tinggi dikelilingi oleh daerah yang tinggi pula. Kuadran II (kiri atas) disebut Low-High (LH), menunjukkan daerah dengan nilai pengamatan rendah namun dikelilingi oleh daerah dengan nilai pengamatan tinggi. Kuadran III (kiri bawah) disebut Low-Low (LL), menunjukkan daerah dengan nilai pengamatan rendah dikelilingi oleh daerah yang rendah pula. Kuadran IV (kanan bawah) disebut High-Low (HL), menunjukkan daerah dengan nilai pengamatan tinggi namun dikelilingi oleh daerah yang memiliki nilai pengamatan rendah [9].

\section{H. Local Indicator of Spatial Autocorrelation (LISA)}

LISA mengidentifikasi bagaimana hubungan antara suatu lokasi pengamatan terhadap lokasi pengamatan yang lainnya. LISA harus memenuhi dua syarat yaitu nilai LISA untuk setiap pengamatan memberi indikasi sejauh mana pengelompokkan spasial yang signifikan dari nilai-nilai yang sama dan jumlah LISA untuk semua pengamatan sebanding dengan gabungan keseluruhan spasial [8]. Adapun indeksnya adalah sebagai berikut [7].

$$
\hat{I}_{i}=\hat{z}_{i} \sum_{j} w_{i j} \hat{z}_{j}
$$

$z_{i}$ dan $z_{j}$ pada persamaan (2.8) merupakan deviasi dari nilai rata-rata.

$$
\hat{z}_{i}=\left(x_{i}-\bar{x}\right) / s
$$

$s$ adalah nilai standar deviasi dari $x_{i}$.

Berikut merupakan pengujian statistik terhadap parameter $I_{i}$.

$\mathrm{H}_{0}: I_{i}=E\left(I_{i}\right)$ (tidak ada autokorelasi spasial pada lokasi ke-i)

$\mathrm{H}_{1}: I_{i} \neq E\left(I_{i}\right)$ (terdapat autokorelasi spasial pada lokasi ke-i) Statistik uji:

$$
Z=\frac{\hat{I}_{i}-E\left(I_{i}\right)}{\sqrt{\operatorname{var}\left(\hat{I}_{i}\right)}}
$$

Dengan $\hat{I}_{i}$ merupakan estimasi indeks LISA, $Z$ merupakan nilai statistik uji indeks LISA, $E\left(I_{i}\right)$ merupakan nilai ekspektasi indeks LISA, $\operatorname{vâr}\left(\hat{I}_{i}\right)$ merupakan nilai varians dari indeks LISA.

$$
\begin{gathered}
E\left(I_{i}\right)=-w_{i .} /(n-1) \\
\operatorname{var}\left(I_{i}\right)=w_{i .}^{(2)} \frac{\left(n-\frac{m_{4}}{m_{2}^{2}}\right)}{(n-1)}-2 w_{i(k h)} \frac{\left(2 m_{4} / m_{2}^{2}-n\right)}{(n-1)(n-2)}-\frac{w_{i .}^{2}}{(n-1)^{2}}
\end{gathered}
$$

Dengan,

$$
\begin{aligned}
& w_{i .}^{(2)}=\sum_{j} w_{i j}^{2}, i \neq j \\
& 2 w_{i(k h)}=\sum_{k \neq i} \sum_{h \neq i} w_{i k} w_{i h} \\
& w_{i .}^{2}=\left(\sum_{j} w_{i j}\right)^{2} \\
& \quad \text { Pengujian ini akan tolak } \mathrm{H}_{0} \text { apabila }\left|Z_{\text {hitung }}\right|>Z_{\left(\frac{\alpha}{2}, n-1\right)} .
\end{aligned}
$$

\section{Flexibly Spatial Scan Statistic}

Spatial scan statistic merupakan salah satu metode statistik yang digunakan untuk mendeteksi cluster pada sebuah lokasi yang berupa titik maupun data agregrat. Metode Flexibly Shaped Spatial Scan Statistic mempunyai power lebih tinggi daripada Circular Spatial Scan Statistic saat cluster yang dideteksi adalah non-circular dan fleksibel terhadap bentuk kantong yang dihasilkan sehingga tidak terbatas pada bentuk lingkaran saja [10].

Algoritma yang digunakan untuk mendapatkan $Z$ dengan pre-specified maximum length $\mathrm{L}$ adalah sebagai berikut.

1. Membentuk himpunan wilayah $\mathrm{Z}$

$$
Z=\left\{Z_{i l(m)} \mid 1 \leq i \leq n, 1 \leq l \leq L, 1 \leq m \leq m_{i l}\right\}
$$

dimana $\mathrm{n}$ adalah banyaknya data pengamatan, $\mathrm{L}$ adalah banyak wilayah maksimum dalam satu kantong dan $\mathrm{m}$ adalah banyak data bangkitan dengan simulasi monteCarlo.

2. Himpunan wilayah $\mathrm{Z}$ dibagi menjadi dua himpunan wilayah baru yakni $\mathrm{Z}_{0}$ dan $\mathrm{Z}_{1}$, dimana $\mathrm{Z}_{0}$ adalah himpunan wilayah dari $\mathrm{Z}$ yang acak dan $\mathrm{Z}_{1}$ juga merupakan himpunan wilayah acak dari $\mathrm{Z}$ selain $\mathrm{Z}_{0}$

3. Buat 2 himpunan baru yakni $Z_{0}$ ' terdiri dari wilayah $Z_{1}$ yang berbatasan dengan $\mathrm{Z}_{0}$ dan $\mathrm{Z}_{1}$ ' terdiri dari wilayah $\mathrm{Z}_{1}$ yang tidak berbatasan dengan $Z_{0}$

4. Ulangi langkah 3 hingga $Z_{0}$ dan $Z_{1}$ menjadi himpunan kosong. 
5. Jika $Z_{1}$ menjadi himpunan kosong terlebih dahulu maka $Z$ adalah berhubungan, jika $\mathrm{Z}_{0}$ kosong terlebih dahulu maka $\mathrm{Z}$ tidak berhubungan.

6. Ulangi langkah 2-5 hingga terbentuk maksimum L wilayah.

Prosedur untuk mendapatkan p-value dengan pendekatan

Monte Carlo adalah sebagai berikut.

1. Menghitung penjumlahan nilai log likelihood ratio tertinggi $\mathrm{t}_{0}$ untuk data riil.

2. Membangun data acak yang ukurannya sama dengan data riil yang dibangun di bawah kondisi $\mathrm{H}_{0}$.

3. Melakukan proses pembentukan scanning window $\mathrm{Z}$ dari data acak yang dibangun berdasarkan kondisi $\mathrm{H}_{0}$.

4. Mencari nilai log likelihood ratio dari setiap scanning window, dan dicatat apakah jumlah kasus yang diamati lebih besar atau lebih kecil dari yang diestimasi, kemudian menjumlahkan nilai log likelihood ratio yang jumlah kasusnya lebih besar dari jumlah yang diestimasi, untuk setiap scanning window. Langkah selanjutnya, mendapatkan penjumlahan nilai log likelihood ratio yang tertinggi dari simulasi pertama pembangunan data acak tersebut.

5. Mengulang langkah 2, 3, dan 4 sebanyak $m$ kali pengulangan/simulasi, sehingga memperoleh $m$ penjumlahan nilai log likelihood ratio tertinggi dari data acak dan data riil.

Hitung p-value, $p=\frac{\text { banyaknya }\left(T(x) \geq t_{0}\right)}{m+1}$

$t_{0}$ menyatakan penjumlahan nilai log likelihood ratio tertinggi. $T(x)$ adalah penjumlahan nilai log likelihood ratio dari data acak yang dibangun di bawah kondisi $\mathrm{H}_{0} . m$ adalah banyaknya simulasi untuk membangun data. Jika $P$-value $<\alpha$ maka tolak $\mathrm{H}_{0}$ yang berarti bahwa window $\mathrm{Z}$ adalah wilayah kantong yang signifikan [10].

Hotspot atau kantong-kantong yang terbentuk dari window $\mathrm{Z}$ diurutkan berdasarkan nilai likelihood-nya dan window $\mathrm{Z}$ yang memiliki nilai likelihood lebih besar daripada yang lain dan nyata pada tingkat signifikansi tertentu akan membentuk hotspot. Hotspot didefinisikan sebagai lokasi atau wilayah terjadinya suatu kejadian yang tidak biasa atau kejadian luar biasa atau disebut juga wilayah kritis [11]. Hotspot juga didefinisikan sebagai lokasi atau wilayah yang konsisten memiliki karakteristik berbeda dengan daerah sekelilingnya [12]. Dalam penelitian ini, hotspot merupakan kumpulan daerah atau wilayah yang rawan terhadap kasus demam berdarah.

\section{J. Peta Tematik dan Peta Kerawanan}

Peta tematik adalah gambaran dari sebagian permukaan bumi yang dilengkapi dengan informasi tertentu, baik di atas maupun di bawah permukaan bumi yang mengandung tema tertentu. Peta kerawanan DBD merupakan model spasial yang digunakan untuk mempresentasikan kondisi dilapangan terkait dengan resiko terjadinya persebaran penyakit DBD yang ada di Kabupaten Lumajang [13].

\section{K. Klasifikasi Kasus dan Metode Natural Break}

ArcView adalah perangkat lunak yang digunakan untuk membangun SIG (Sistem Informasi Geografis). Dalam ArcView, salah satu metode pengklasifikasian yang digunakan untuk menyusun peta tematik adalah metode natural break. Metode natural break menghasilkan variasi minimum untuk wilayah yang berada pada satu kelompok tema. Algoritma dari metode natural break adalah sebagai berikut [14].

1. Bagi wilayah sebanyak h kelompok dari $\mathrm{n}$ wilayah. Banyak anggota tiap kelompok minimal 1 dan maksimal adalah sejumlah n-(q-1); q = 1,2, .., h.

2. Hitung rata-rata dari setiap kelompok.

3. Hitung jumlahan standar deviasi kuadrat dari setiap kelompok kombinasi wilayah.

4. Pembagian kelompok dengan jumlahan standar deviasi kuadrat terkecil adalah pembagian wilayah yang optimum.

\section{Demam Berdarah Dengue (DBD)}

Demam berdarah dengue (DBD) adalah penyakit yang disebabkan oleh virus Dengue dari genus Flavivirus, famili Flaviviridae melalui gigitan nyamuk Aedes aegypti dan Aedesalbopictus. Adapun nyamuk Aedes aegypti memiliki kemampuan terbang mencapai radius 100-200 meter. Oleh karena itu, jika di suatu lingkungan terkena kasus DBD, maka masyarakat yang berada pada radius tersebut harus waspada [15]. Nyamuk Aedes aegypti lebih menyukai tempat yang gelap, berbau, dan lembap. Tempat perindukan yang sering dipilih Aedes aegypti adalah kawasan yang padat dengan sanitasi yang kurang memadai, terutama digenangan air dalam rumah, seperti pot, vas bunga, bak mandi atau tempat penyimpanan air lainnya seperti tempayan, drum, atau ember plastik [16].

\section{METODOLOGI PENELITIAN}

\section{A. Sumber Data dan Variabel Penelitian}

Data yang digunakan pada penelitian ini adalah data sekunder yang diperoleh dari Dinas Kesehatan Kabupaten Lumajang. Data tersebut berisi tentang jumlah kejadian kasus deman berdarah dengue (DBD) di setiap kecamatan di Kabupaten Lumajang pada Tahun 2014 hingga 2016.

Varibel yang digunakan pada penelitian ini adalah jumlah kasus DBD masing-masing kecamatan di Kabupaten Lumajang pada tahun 2014 hingga 2016.

\section{B. Langkah Analisis}

Langkah-langkah analisis yang akan dilakukan berdasarkan dengan tujuan adalah sebagai berikut.

1. Mendeskripsikan pola persebaran kasus DBD yang ditemukan di tiap kecamatan di Kabupaten Lumajang pada tahun 2014 - 2016

a. Mendeskripsikan tren dan persebaran kasus DBD dengan boxplot.

b. Memetakan kejadian kasus DBD dan membandingkan pola yang terbentuk dari tahun ke tahun secara deskriptif dengan peta tematik.

2. Mengetahui dependensi spasial kasus DBD di Kabupaten Lumajang antar kecamatan dengan Spatial Pattern Analysis. 
a. Menghitung ukuran dependensi spasial menggunakan indeks Moran's I

b. Menguji dependensi spasial menggunakan indeks Moran's I

c. Membuat dan mengidentifikasi Moran's Scatterplot

3. Menganalisis wilayah yang menjadi hotspot maupun coldspot kejadian kasus DBD menggunakan hasil pengujian Local Indicator of Spatial Autocorrelation (LISA)

4. Mendeteksi hotspot rawan kejadian kasus DBD dengan pendekatan Flexibly Shaped Spatial Scan Statistic.

a. Scatterplot antara jumlah kasus DBD dan jumlah populasi setiap kecamatan di Kabupaten Lumajang

b. Mengidentifikasi kandidat cluster/hotspot dengan algoritma yang ada di metode Flexibly Shaped Spatial Scan Statistic

c. Menguji signifikansi cluster dengan simulasi Monte Carlo pada setiap cluster untuk mendapatkan P-value

d. Membuat peta kerawanan kantong kasus DBD berdasarkan cluster yang signifikan metode Flexibly Shaped Spatial Scan Statistic

e. Menginterpretasikan kantong kasus DBD dengan metode Flexibly Shaped Spatial Scan Statistic sehingga diperoleh prioritas lokasi pengendalian penyakit DBD

\section{ANALISIS DAN PEMBAHASAN}

\section{A. Persebaran Kasus DBD di Kabupaten Lumajang}

Boxplot menunjukkan bahwa secara stastistik, rata-rata jumlah kasus DBD yang ditemukan pada 21 kecamatan di Kabupaten Lumajang terjadi peningkatan setiap tahunnya.

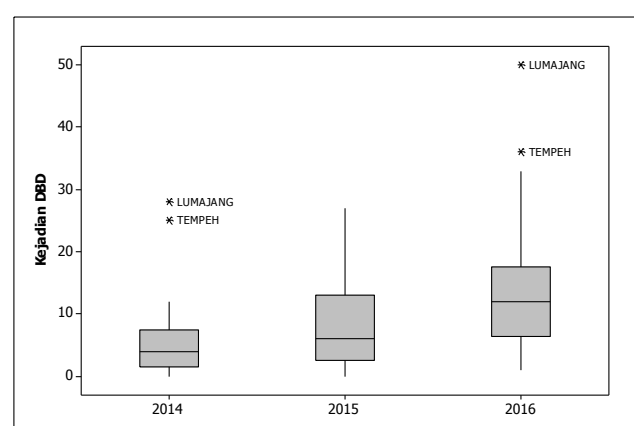

Gambar 4. Boxplot Kasus DBD Tahun 2014-2016.

Tabel 1.

Nilai Rata-Rata, Median, Standar Deviasi, Minimum dan Maksimum Kasus DBD Tahun 2014-2016

\begin{tabular}{cccccc}
\hline \hline $\begin{array}{c}\text { Tahu } \\
\mathrm{n}\end{array}$ & $\begin{array}{c}\text { Rata- } \\
\text { Rata }\end{array}$ & $\begin{array}{c}\text { Media } \\
\mathrm{n}\end{array}$ & $\begin{array}{c}\text { Standar } \\
\text { Deviasi }\end{array}$ & $\begin{array}{c}\text { Minimu } \\
\mathrm{m}\end{array}$ & $\begin{array}{c}\text { Maksimu } \\
\mathrm{m}\end{array}$ \\
\hline 2014 & 6,14 & 4,00 & 7,51 & 0,00 & 28,00 \\
2015 & 8,52 & 6,00 & 7,65 & 0,00 & 27,00 \\
2016 & 14,86 & 12,00 & 12,13 & 1,00 & 50,00 \\
\hline \hline
\end{tabular}

Terdapat 4 kecamatan dengan kasus DBD yang sangat tinggi pada tahun 2014 yaitu kecamatan Lumajang sebanyak 28 kasus, selanjutnya adalah Kecamatan Tempeh, Kecamatan Randuagung, dan Kecamatan Yosowilangun. Indikasi kenaikan pada kasus DBD di Kabupaten Lumajang pada tahun 2016 ditunjukkan dengan meningkatnya rata-rata jumlah kasus DBD yang semula sebanyak 8,52 kasus pada tahun 2015, meningkat sebanyak 6,34 kasus menjadi 14,86 kasus pada tahun 2016. Hal ini terjadi karena terjadi peningkatan jumlah kasus DBD pada beberapa kecamatan, salah satunya adalah Kecamatan Klakah yang semula ditemukan 7 kasus pada tahun 2014 meningkat menjadi 33 kasus pada tahun 2016. Selanjutnya diikuti oleh kecamatan Lumajang dan Sukodono, dimana di Kecamatan Lumajang mengalami peningkatan sebanyak 22 kasus dari 28 kasus pada tahun 2014 menjadi 50 kasus pada tahun 2016 sementara itu di Kecamatan Sukodono mengalami peningkatan 17 kasus dari 2 kasus di tahun 2014 menjadi 19 kasus di tahun 2016.

Peningkatan rata-rata pada jumlah kasus DBD tidak menyeluruh pada semua kecamatan di Kabupaten Lumajang, oleh karena itu analisis yang dilakukan selanjutnya adalah pemetaan kejadian kasus DBD yang ditemukan di setiap kecamatan di Kabupaten Lumajang pada Tahun 2014 hingga 2016 dengan peta tematik yang bertujuan untuk membandingkan pola persebaran antar kecamatan dari tahun ke tahun. Persebaran jumlah kasus DBD pada tahun 20142016 dengan peta tematik ditunjukkan pada Gambar 5-7 sebagai berikut:

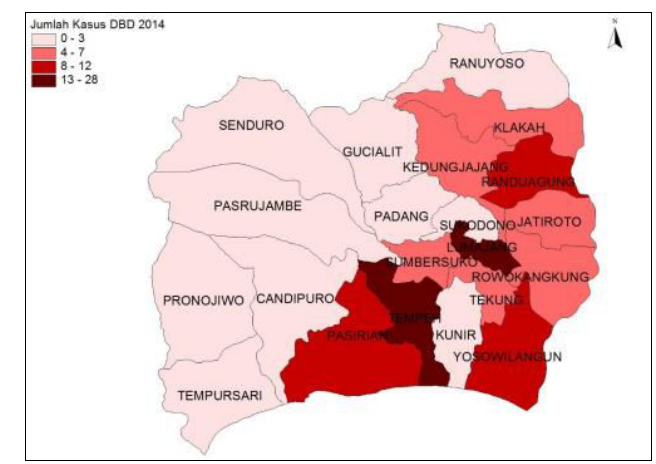

Gambar 5. Persebaran Kasus DBD Menurut Kecamatan di Kab. Lumajang Tahun 2014.

Jumlah Kasus DBD di Kecamatan Lumajang dan Kecamatan Tempeh merupakan jumlah kasus yang paling tinggi pada Tahun 2014 dengan 28 kasus di Kecamatan Lumajang dan 25 kasus di Kecamatan Tempeh. Kejadian kasus DBD yang cenderung tinggi terjadi pada Kecamatan Randuagung, Yosowilangun dan Pasirian, masing-masing sebanyak 12, 10 dan 8 kasus DBD.

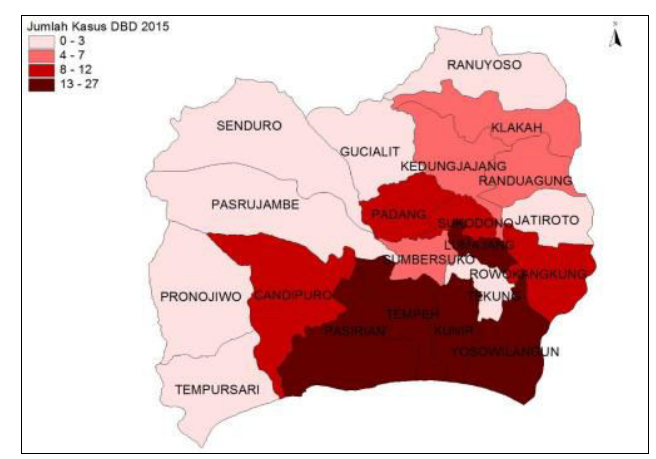

Gambar 6. Persebaran Kasus DBD Menurut Kecamatan di Kab. Lumajang Tahun 2015.

Berbeda dengan Tahun 2014, pada Tahun 2015 terjadi peningkatan jumlah kasus DBD paling tinggi yang semula hanya 2 kecamatan menjadi 5 kecamatan, yaitu Kecamatan Lumajang, Tempeh, Pasirian, Kunir dan Yosowilangun, 
masing-masing sebanyak 27, 24, 17, 17 dan 16 kasus DBD. Kecamatan yang memiliki jumlah kasus DBD tertinggi masih ditempati Kecamatan Lumajang dengan 27 Kasus DBD dan mengalami penurunan sebanyak 1 kasus dari Tahun 2014. Kecamatan yang memiliki kasus DBD tertinggi merupakan kecamatan yang berdekatan yakni Kecamatan Pasirian, Tempeh, Kunir dan Yosowilangun.

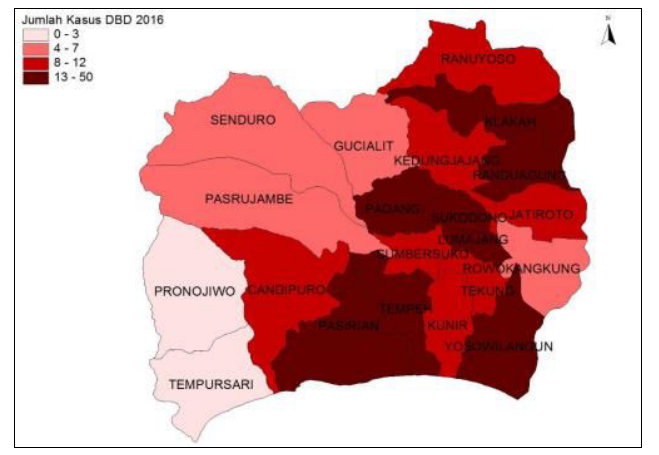

Gambar 7. Persebaran Kasus DBD Menurut Kecamatan di Kab. Lumajang Tahun 2016.

Pada Tahun 2016 jumlah kasus DBD paling tinggi bertambah menjadi 8 Kecamatan, yakni Kecamatan Lumajang, Tempeh, Klakah, Yosowilangun, Sukodono, Randuagung, Pasirian dan Padang dengan jumlah kasus yang paling tinggi 50 di Kecamatan Lumajang. Di Kecamatan Lumajang terjadi peningkatan jumlah sebanyak 23 dari 27 kasus di Tahun 2015.

\section{B. Spatial Pattern Analysis Kasus DBD di Kabupaten Lumajang \\ Pola persebaran kejadian DBD pada tahun 2014 di} Kabupaten Lumajang yaitu menyebar di setiap kecamatannya, sedangkan pada tahun 2015 dan 2016 pola persebaran penyakit DBD di setiap kecamatan di Kabupaten Lumajang mengelompok. Nilai indeks Moran's I berkisar antara -1 hingga 1, sehingga dapat diketahui pula bahwa pada tahun 2014, 2015 dan 2016 dependensi spasial antar kecamatan terkait kasus DBD sangat rendah.

Tabel 2.

Nilai Moran's I

\begin{tabular}{ccccc}
\multicolumn{5}{c}{ Nilai Moran's I } \\
\hline \hline $\begin{array}{c}\text { Tahu } \\
\mathrm{n}\end{array}$ & $\mathrm{I}$ & $\mathrm{I}_{0}$ & & Kesimpulan \\
\hline 2014 & - & - & $\mathrm{I}<\mathrm{I}_{0}$ & Pola Menyebar \\
& 0.053 & 0.05 & & \\
2015 & 0.179 & - & $\mathrm{I}>\mathrm{I}_{0}$ & Pola Mengelompok \\
& - & - & & \\
2016 & 0.015 & 0.05 & $\mathrm{I}>\mathrm{I}_{0}$ & Pola Mengelompok \\
\hline \hline
\end{tabular}

Pengujian signifikasi pada indeks Moran's I untuk mengetahui apakah terdapat autokorelasi spasial antar kecamatan terkait kasus DBD.

Tabel 3.

Uji Signifikansi Moran's I

\begin{tabular}{|c|c|c|c|}
\hline $\begin{array}{c}\text { Tahu } \\
\mathrm{n}\end{array}$ & $Z_{\text {hitung }}$ & $\begin{array}{c}Z_{\alpha / 2} \\
10 \\
\%\end{array}$ & Keputusan \\
\hline 2014 & $\begin{array}{c}- \\
0.0665\end{array}$ & 1.65 & $\begin{array}{c}\text { Gagal Tolak } \\
\mathrm{H}_{0}\end{array}$ \\
\hline $\begin{array}{l}2015 \\
2016 \\
\end{array}$ & $\begin{array}{l}1.8496 \\
0.2499 \\
\end{array}$ & $\begin{array}{l}1.65 \\
1.65 \\
\end{array}$ & $\begin{array}{c}\text { Tolak } \mathrm{H}_{0} \\
\text { Gagal Tolak }\end{array}$ \\
\hline
\end{tabular}

$\mathrm{H}_{0}$

Tabel 3. menyatakan bahwa pada Tahun 2014 dan 2016 nilai statistik uji $\mathrm{Z}$ pada kedua tahun tersebut tidak signifikan pada taraf $10 \%$, sehingga keputusan yang diambil dalam pengujian signifikansi indeks Moran's I adalah gagal tolak $\mathrm{H}_{0}$. Disimpulkan bahwa tidak ada autokorelasi spasial atau tidak ada dependensi spasial antara jumlah kasus DBD pada kecamatan satu dengan kecamatan lain yang letaknya berdekatan. Sedangkan pada tahun 2015 nilai statistik uji Z pada tahun tersebut signifikan pada taraf $10 \%$, sehingga keputusan yang diambil dalam pengujian signifikansi indeks Moran's I adalah tolak $\mathrm{H}_{0}$. Artinya, bahwa ada autokorelasi spasial atau ada dependensi spasial antara jumlah kasus DBD pada kecamatan satu dengan kecamatan lain yang letaknya berdekatan.

\section{Local Indicator of Spatial Autocorrelation (LISA) Kasus DBD di Kabupaten Lumajang}

Analisis wilayah yang menjadi hotspot dan coldspot kejadian DBD menggunakan hasil pengujian LISA didasarkan pada adanya aspek autokorelasi spasial pada suatu wilayah (hubungan suatu wilayah dengan wilayah lainnya). Hasil pendeteksian hotspot dan coldspot kejadian DBD di Kabupaten Lumajang.

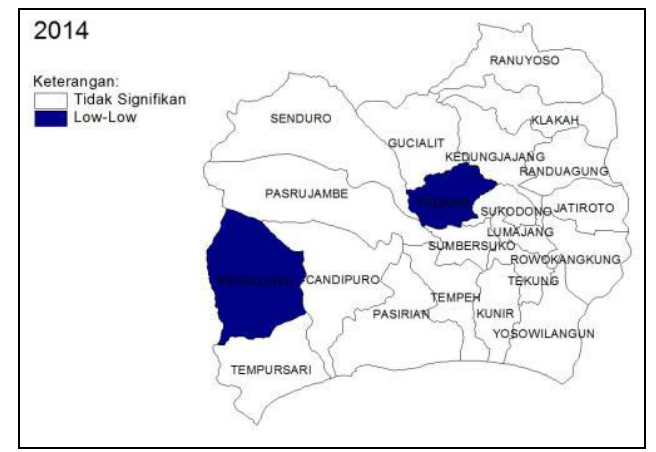

Gambar 11. Peta Hasil Analisis LISA Kasus DBD pada Tahun 2014.

Berdasarkan Gambar 11. diperoleh informasi bahwa pada Tahun 2014 terdapat 2 wilayah berwarna biru tua merupakan wilayah yang signifikan termasuk dalam kuadran III terdiri dari Kecamatan Padang dan Pronojiwo.

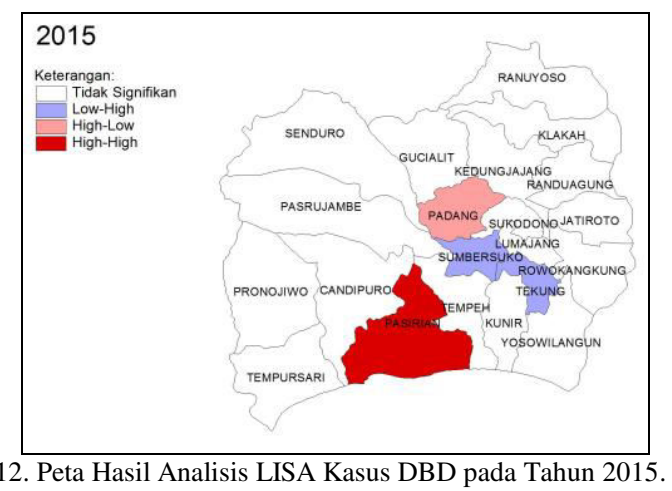

Gambar 12. Peta Hasil Analisis LISA Kasus DBD pada Tahun 2015.

Gambar 12. menunjukkan bahwa pada Tahun 2015 memiliki kecamatan yang signifikan termasuk dalam Kuadran I (HighHigh) adalah wilayah yang berwarna merah yaitu Kecamatan Pasirian. Hal ini menunjukkan bahwa kecamatan tersebut memiliki autokorelasi positif, artinya kecamatan tersebut 
memiliki jumlah kasus DBD yang tinggi dan dikelilingi oleh kecamatan lain dengan jumlah kasus DBD yang tinggi pula. Dengan demikian, Kecamatan Pasirian dapat dikatakan sebagai hotspot kasus DBD karena berpotensi sebagai pusat persebaran penyakit DBD di Kabupaten Lumajang.

Selain itu, Kecamatan termasuk dalam kuadran IV (HighLow) yang signifikan masuk kedalam kuadran ini adalah wilayah yang berwarna merah muda yaitu Kecamatan Padang memiliki autokorelasi spasial negatif atau berpola pencilan, dengan jumlah kasus DBD yang tinggi di Kecamatan tersebut namun dikelilingi oleh wilayah yang memiliki jumlah kasus DBD yang rendah.

Selanjutnya adalah wilayah yang signifikan termasuk dalam kuadran II (Low-High), diberi warna biru muda. Wilayah tersebut yaitu Kecamatan Sumbersuko dan Tekung memiliki autokorelasi spasial negatif atau berpola pencilan dengan jumlah kasus DBD pada kecamatan tersebut rendah (coldspot) sedangkan wilayah sekitarnya memiliki jumlah kasus DBD yang tinggi.

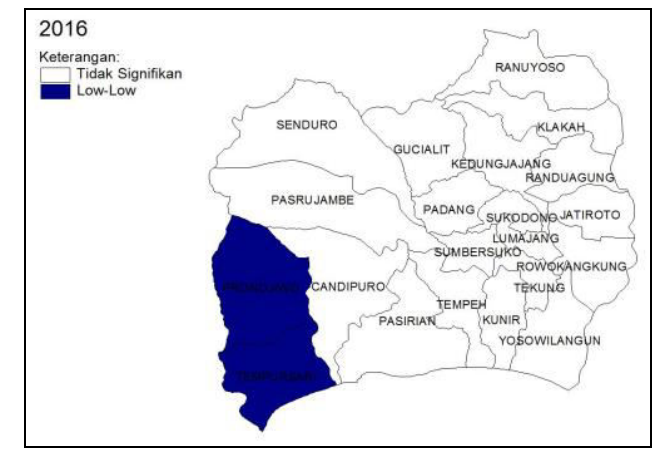

Gambar 13. Peta Hasil Analisis LISA Kasus DBD pada Tahun 2016.

Berdasarkan Gambar 13. diperoleh informasi bahwa pada Tahun 2016 hanya memiliki satu kantong atau hotspot yang signifikan yaitu Kuadran III (Low-Low). Wilayah yang berwarna biru tua adalah wilayah yang signifikan termasuk dalam kuadran III terdiri dari Kecamatan Tempursari dan Pronojiwo.

\section{Peta Kerawanan Kasus DBD di Kabupaten Lumajang dengan Metode Flexibly Shaped Spatial Scan Statistic}

Flexibly Shaped Spatial Scan Statistic menyusun peta kerawanan dengan memperhatikan populasi dalam kecamatan,

Tabel 4.

Korelasi Jumlah Kasus DBD dan Kepadatan Penduduk Kabupaten Lumajang

\begin{tabular}{crl}
\hline \hline $\begin{array}{l}\text { Tahu } \\
\mathrm{n}\end{array}$ & $\mathrm{r}_{\mathrm{xy}}$ & $\begin{array}{l}\text { P- } \\
\text { value }\end{array}$ \\
\hline 2014 & 0.55 & 0.009 \\
& 6 & \\
2015 & 0.57 & 0.007 \\
& 3 & \\
2016 & 0.74 & 0.000 \\
& 2 & \\
\hline \hline
\end{tabular}

Tabel 4. menunjukkan bahwa, jumlah kasus DBD Tahun 2016 memiliki korelasi yang kuat dengan kepadatan penduduknya. Sedangkan, pada dua tahun sebelumnya jumlah kasus DBD memiliki korelasi yang sedang dengan kepadatan penduduknya.
Analisis dalam menyusun peta kerawanan dengan metode Flexibly Shaped Spatial Scan Statistic menggunakan pengujian Monte Carlo.

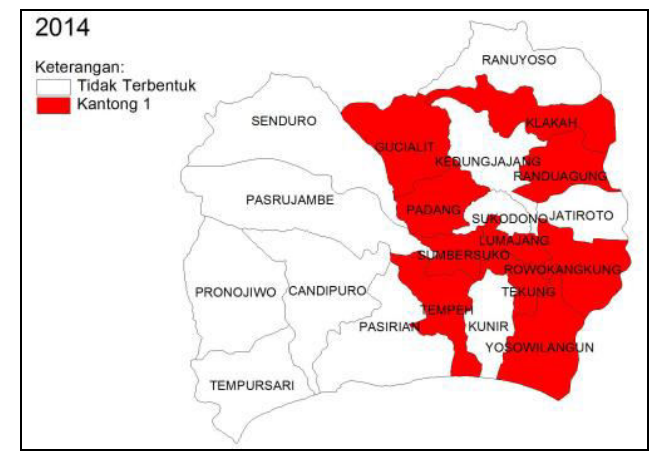

Gambar 17. Peta Kerawanan DBD dengan Flexibly Shaped Spatial Scan Statistic pada Tahun 2014.

Hasil analisis metode Flexibly Shaped Spatial Scan Statistic pada Gambar 17. menunjukkan bahwa pada Tahun 2014 terdapat cluster rawan meliputi Kecamatan Gucialit, Padang, Lumajang, Sumbersuko, Tempeh, Yosowilangun, Tekung, Rowokangkung, Randuagung, dan Klakah yang mana letak kecamatan tersebut berdekatan.

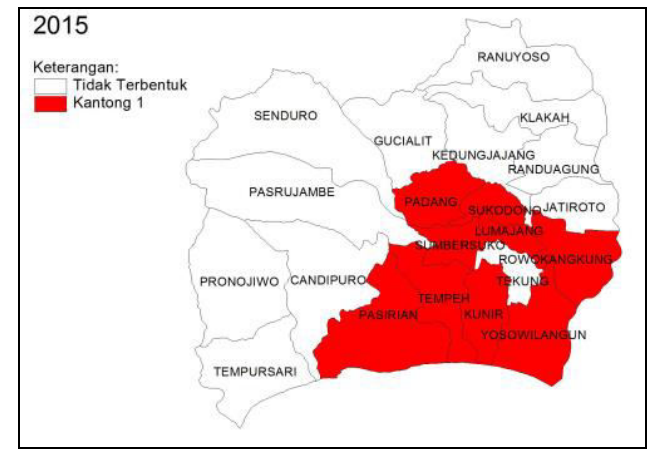

Gambar 18. Peta Kerawanan DBD dengan Flexibly Shaped Spatial Scan Statistic pada Tahun 2015.

Hasil analisis metode Flexibly Shaped Spatial Scan Statistic pada Tahun 2015 juga hanya terdapat satu kantong dengan resiko tertinggi meliputi Kecamatan Padang, Lumajang, Sukodono, Sumbersuko, Tempeh, Kunir, Yosowilangun, Rowokangkung dan Pasirian yang mana letak kecamatan tersebut berdekatan.

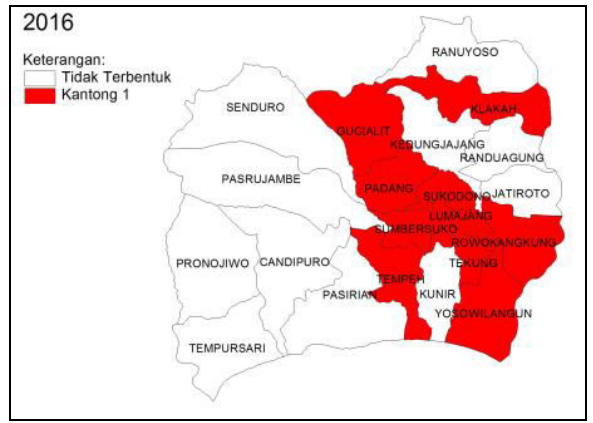

Gambar 19. Peta Kerawanan DBD dengan Flexibly Shaped Spatial Scan Statistic pada Tahun 2016.

Hasil analisis metode Flexibly Shaped Spatial Scan Statistic pada Tahun 2016 juga hanya terdapat satu kantong dengan resiko tertinggi meliputi Kecamatan Gucialit, Padang, 
Lumajang, Sukodono, Sumbersuko, Tempeh, Tekung, Yosowilangun, Rowokangkung dan Klakah yang mana letak kecamatan tersebut berdekatan.

Peta kerawanan kasus DBD yang tersusun dari metode Flexibly Shaped Spatial Scan Statistic selama Tahun 2014 sampai 2016 disajikan pada Gambar 20 sebagai berikut.

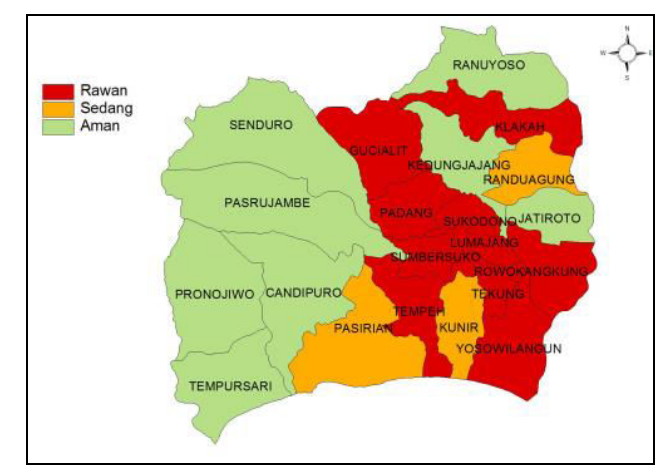

Gambar 20. Peta Kerawanan Agregat DBD dengan Flexibly Shaped Spatial Scan Statistic pada Tahun 2014-2016.

Gambar 20. menginformasikan bahwa Kecamatan Gucialit, Klakah, Padang, Sukodono, Lumajang, Sumbersuko, Tempeh, Tekung, Rowokangkung dan Yosowilangun adalah kecamatan yang rawan atau merupakan kantong kasus DBD berdasarkan metode Flexibly Shaped Spatial Scan Statistic. Sedangkan kecamatan dengan tingkat kerawanan yang sedang yaitu terdiri dari Kecamatan Randuagung, Pasirian dan Kunir juga perlu diwaspadai. Kumpulan kecamatan dengan tingkat kerawanan kasus DBD yang tinggi dan sedang tersebut terletak berdekatan.

\section{KESIMPULAN DAN SARAN}

Boxplot menunjukkan bahwa secara statistik, jumlah kasus DBD yang ditemukan pada 21 kecamatan di Kabupaten Lumajang mengalami tren meningkat tiap tahunnya. Rata-rata jumlah kasus DBD selalu mengalami kenaikan dari Tahun 2014 hingga 2016. Kecamatan Lumajang adalah kecamatan yang selalu memiliki jumlah kasus DBD yang tertinggi atau maksimum pada Tahun 2014 hingga 2016. Pola persebaran kejadian kasus DBD pada Tahun 2014 menyebar di setiap kecamatannya, sedangkan pada Tahun 2015 dan 2016 pola persebarannya mengumpul. Pada Tahun 2015 terjadi autokorelasi spasial atau ada dependensi spasial antara jumlah kasus DBD pada kecamatan satu dengan kecamatan lain yang letaknya berdekatan. Kecamatan Gucialit, Klakah, Padang, Sukodono, Lumajang, Sumbersuko, Tempeh, Rowokangkung, Yosowilangun dan Tekung merupakan kantong kecamatan yang teridentifiksi rawan kasus DBD berdasarkan hasil analisis dengan menggunakan metode Flexibly Shaped Spatial Scan Statistic.

Penelitian ini hanya memfokuskan pada pembentukan peta kerawanan kasus DBD tanpa memperhatikan faktor lain yang menyebabkan kecamatan tersebut menjadi kecamatan yang rawan. Sehingga diharapkan penelitian selanjutnya juga dapat meneliti faktor lain yang menyebabkan rawannya kasus DBD di setiap kecamatan sebagai tambahan informasi agar dapat lebih spesifik menentukan program pengendalian penyakit DBD di Kabupaten Lumajang.

\section{DAFTAR PUSTAKA}

[1] K. Lestari, "Epidemiologi dan Pencegahan Demam Berdarah Dengue (DBD) di Indonesia," Jatinagor, 2007.

[2] Arrowiyah, "Spatial Pattern Analysis Kejadian Penyakit Demam Berdarah Dengue untuk Informasi Early Warning Bencana di Kota Surabaya," Surabaya, 2011.

[3] F. A. Siregar, "Epidemiologi dan Pemberantasan Demam Berdarah Dengue (DBD) di Indonesia," Medan, 2004.

[4] F. Hibatullah, "Pola Persebaran dan Peta Kerawanan Kejadian Kasus Pneumonia Balita di Kota Surabaya," Surabaya, 2016.

[5] S. M. Ross, Introduction to probability and statistics for engineers and scientists. London: Academic Press/Elsevier, 2009.

[6] Junaidi, "Deskripsi Data Melalui Boxplot," Jambi, 2014.

[7] J. Lee and D. W. Wong, Statistical Analysis with ArcView GIS. Canada: John Willey \& Sons, Inc, 2001.

[8] M. Herold, H. Couclelis, and K. C. Clarke, "The Role of Spatial Metrics In The Analysis and Modeling of Urban Land Use Change," Comput. Environ. Urban Syst., vol. 29, no. 4, pp. 369399, 2003.

[9] Y. Kartika, "Pola Penyebaran Spasial Demam Berdarah Dengue di Kota Bogor Tahun 2015," Bogor, 2007.

[10] T. Tango and K. Takahashi, "A Flexibly Shaped Spatial Scan Statistic for Detecting Clusters," Int. J. Health Geogr., vol. 4, no. 11,2005

[11] G. P. Patil and T. C., "Upper Level Set Scan Statistic for Detecting Arbitarily Shaped Hotspots.," Enviromental Ecol. Stat., vol. 11, pp. 183-197, 2003.

[12] M. Haran, J. Molineros, and G. P. Patil, "Large Scale Plant Diasease Forecasting. Technical Report Number 2006-0530," in 7th Annual International Conference on Digital Government Research, 2006.

[13] B. Barus and W. U.S., "Sistem Informasi Geografi: Sarana Manajemen Sumberdaya," Bogor, 2000.

[14] Expert Health Data Programming, "What is Jenks Natural Breaks," 2014. [Online]. Available: http://www.ehdp.com/vitalnet/breaks1.htm. [Accessed: 11-Jan-2018].

[15] Dinas Kesehatan Kota Surabaya, "Profil Kesehatan Kota Surabaya Tahun 2013," Surabaya, 2014.

[16] T. Tobing, "Pemodelan Kasus DBD di Jawa Timur dengan Model Poisson dan Binomial Negatif,” IPB, 2011. 